\title{
The Concept of Sustainable Architecture on Public Open Space Design in the Waterfront Area of Ternate City (Case Study: Area Tapak I)
}

\author{
Endah Harisun ${ }^{1, *}$ \\ ${ }^{1}$ Programme of Study in Architecture, Faculty of Engineering, Khairun University, Ternate, Indonesia \\ ${ }^{*}$ Corresponden Author, e-mail: endah.harisun@unkhair.ac.id
}

\begin{abstract}
The phenomenon of the development of the city of Ternate in recent years shows that there has been a crisis in the availability of public space. with the construction of malls and offices, has the opportunity to create a distance between the layers of society and the beach as the identity of the city of Ternate itself. Based on observations, especially in the coastal area which is one of the problems of the city of Ternate related to the inability of the Ternate area as a whole the city provides public open space, where this can be seen from the orientation of the development of the city making the coastal area a 'back' and a place to dispose of various types of waste, thus causing environmental degradation both ecologically, spatially and visually. This research uses descriptive qualitative research method, which is a stage of landscape design in the form of combining sustainable concepts to minimize the negative impact of construction on the environment.
\end{abstract}

Keywords: public open space, sustainable development, waterfront area

\section{INTRODUCTION}

The development of waterfront cities in Indonesia is a potential problem that must be addressed more comprehensively because Indonesia has the longest coastline in the world. Based on PP47 / 97 (National Spatial Planning), in Indonesia, there are 516 cities that are the mainstay and 216 of them are cities located on the banks of rivers or lakes [1].

Ternate City is one of the coastal cities that in the last few years carried out reclamation as an effort to develop a city with a waterfront concept so as to form an image of the city marked by a waterfront identity. city. The development process that is being and will be carried out needs control to overcome the effects of excessive land use by structuring public active spaces that can be of economic and social value.

According to the mayor of Ternate, quoted in the Malut Post Online newspaper, the condition of the city to be developed is the availability of open space around $30 \%$ of the urban area.

But in its development, the seaside city region experienced ups and downs. When the role of water transportation was diverted by land transportation, the coastal area which was originally a central location for urban activities has shifted its orientation to land areas. This causes the coastal areas to be poorly maintained, even with the construction of the Hypermart building, making the seaside city area in Ternate suffer a setback in orientation. Hypermart building area when viewed from the sea into a seedy building. This is very inconsistent with the principles of a waterfront city.

\section{METHODS}

a. Types of research

This research is descriptive qualitative, wherefrom the data obtained is reviewed based on existing theories, so as to produce a concept that will be applied into the form of design, related to the existence of Public Open Space in the waterfront city of Ternate City with a sustainable development approach.

\section{b. Research sites}

For Administratively, the research site is located at site Tapak I of Ternate City, which is generally part of the beach reclamation area (waterfront city area) and initially functioned as a public open area but is now the location of a Hypermart building.

c. Design Process

Booth [2] suggested that the landscape design process has several stages, namely;

\section{Project Acceptance}

In this first stage, the research proposal was received and agreed by both parties, namely the landscape architect and the client. At the first meeting, the client explained his wishes to the landscape architect, and then an agreement was reached between the two parties. Next, the landscape architect prepares a detailed proposal that includes services, 
products, and costs. If the client agrees then both parties sign the contract.

\section{Research and Analysis (Research and Analysis)}

Furthermore, landscape architects need to prepare a site plan and carry out an inventory of sites or data collection stages and then conduct an analysis (data evaluation). Visiting (survey) directly to the site is important to complete this stage. Next is interviewing the owner of the site in this case the Ternate City Planning Office and developing a program at this stage.

Design consists of;

a. Ideal Functional Diagram,

b. Site-Related Functional Diagram,

c. Concept plan

d. Study of form composition (Form Composition Study)

e. Initial design (Preliminary Master Plan),

f. Schematic Design

g. g. Master Plan

h. Design development

3. Construction Drawings

\section{RESULTS AND DISCUSSION}

\section{a. Basic Design}

The idea raised from a park is "The Concept of Public Open Space on the Outer Banks of Ternate City With Continuous Support" which can accommodate community activities and can supply its own energy needs.

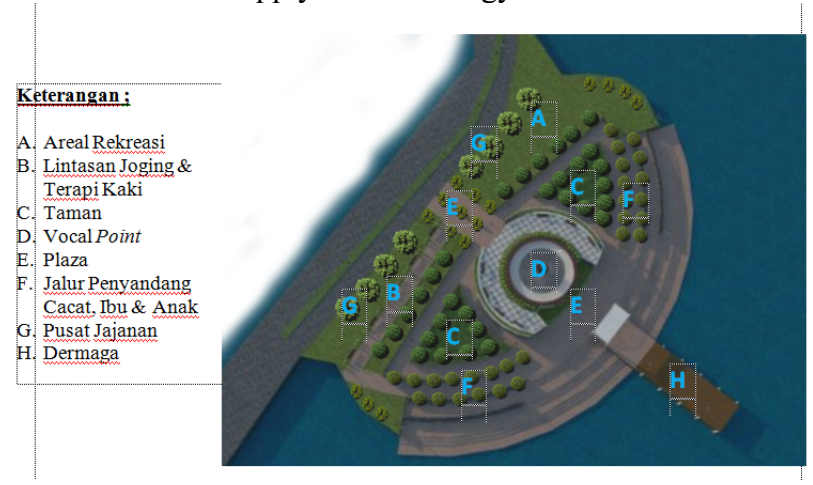

Figure 1. Master Plan

\section{b. Site Management Plan}

Planned site processing, utilizing existing reclamation for green space construction, pedestrian construction and fountains, while for additional reclamation functions used for pier and bridge construction.

Determination of the function of the outer space in the macro, divided into; circulation room: for pedestrian paths and circulation of people with disabilities. Passive green space: specifically a garden for environmental air. Active green space (living space): for recreational activities. Outdoor activity space: for jogging, healthy walking, biking, and others.
Vegetable roads and supports will give an idea of this activity zone. Explaining public and private spaces will minimize user conflicts with others [3]

Reviewing the literature on urbanization and other related studies shows that the variables on the aesthetics of the landscape and the quality of the desired place have been dealt with separately. [4]. In an effort to create a public open space that not only functions as a means of social interaction but also creates aesthetically integrated macro conditions, this is related to the design of a circulation system at the planning location on the waterfront of Ternate, which is designed with regard to activities in the area, and the circulation system designed in the Public Spaces area includes pedestrian paths, jogging lanes, and disabled people, and for circulation of four-wheeled and two-wheeled vehicles use the main road with lots of parking places placed along the main road.
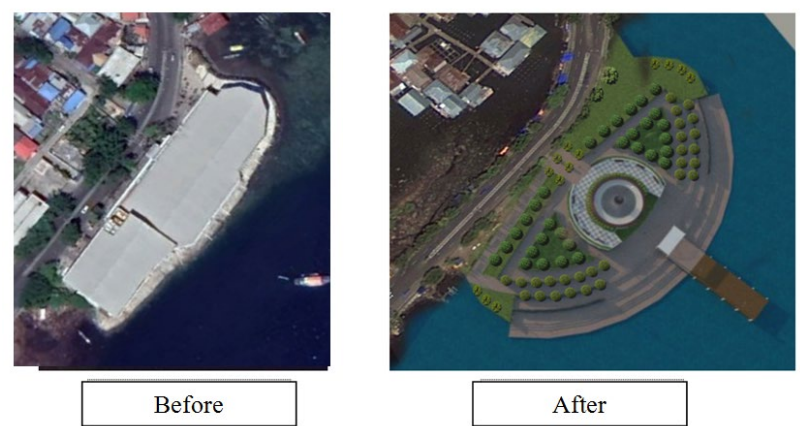

Figure 2. Site Design

\section{c. Pedestrian Way}

In general, there are several ways to achieve the chosen goal. The probability of deciding in a certain way decreases with the appropriate mileage [5]. Pedestrian paths are designed with a variety of tracks, such as walking straight, climbing, and using stairs. This can create a different atmosphere and not seem monotonous. For more details related to the design of pedestrian paths in the Public Open Space, can be seen in the following figure;

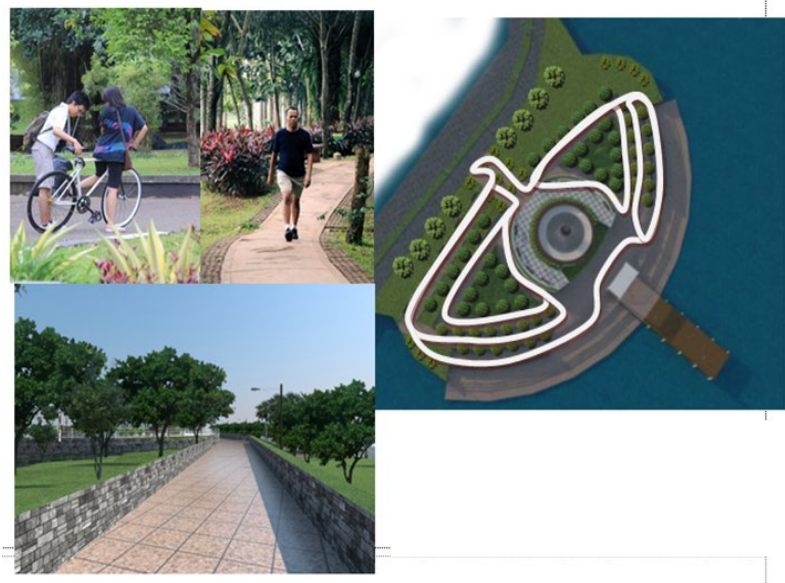

Figure 3. Pedestrian Way trajectory 


\section{Disabled, Mother and Child Areas}

There is a special area called "Disabled Areas, Mothers and Children", in this area mothers can invite their toddlers to play without being disturbed by other park users' activities besides mothers chatting while looking after their toddlers. The application of sloping roads makes it possible for people with physical disabilities and wheelchairs to pass so that the needs of all people in public spaces can be met fairly.

\section{Jogging Tracks \& Foot Therapy}

One of the goals of the design of the Public Open Space in the seaside area of Ternate City as a place to exercise, the circulation used in the design of this Public Space, is the jogging track, and foot therapy.

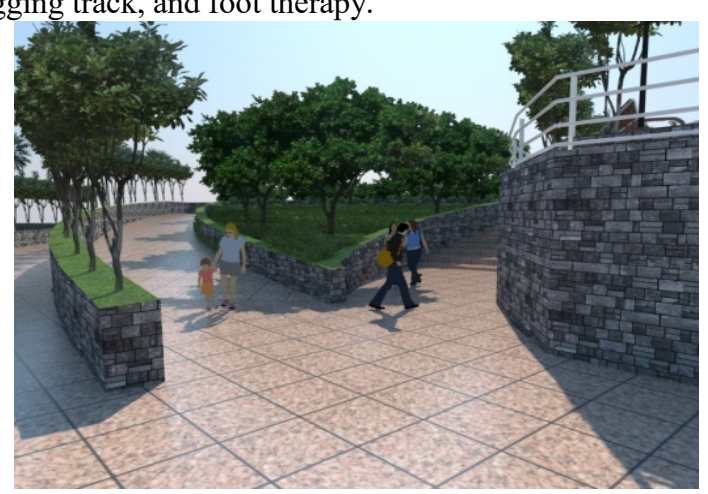

Figure 4. Disabled, Mother and Child Areas

\section{d. Outdoor Element Design}

\section{Sequence and Serial Vision}

Serial vision is the observer's visual impression when walking at a steady pace. The landscape in this design area will always change sequentially to form a visual sequence [6]. The pedestrian path is directed to the path that is designed to reach the peak point, the Focus Point so that the emotional influence of the pedestrian can be achieved while aiming to explore feelings, users can feel the uniqueness and splendor of the Focus Point. The focal point is designed with aesthetic details of the elements of outdoor space.

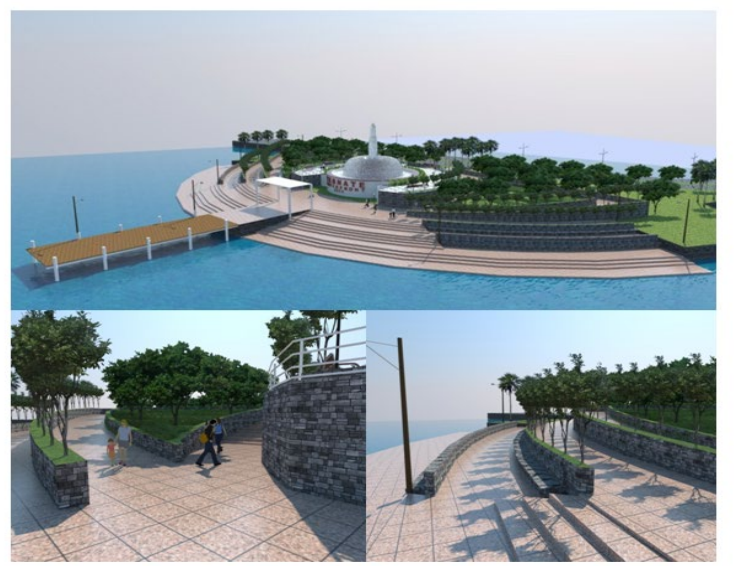

Figure 5. The Concept of Sequence and Serial Vision

\section{Focal Point}

The focal point functions as a center or as a symbol of meeting or informing people that they have reached their destination, and for more details related to the use of Focal Points in the design of Ternate's Public Open Space, can be seen in the following figure;

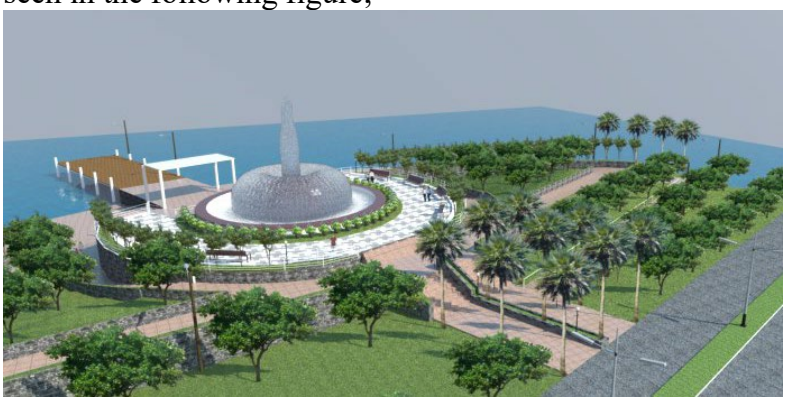

Figure 6. The concept of Focal Points

e. Site Design Elements (mass and garden)

Mass as site elements are elements that make up outer space consisting of buildings and vegetation elements, while parks are spaces bounded by landscapes (lower horizontal boundary) and vegetation or building masses (vertical boundaries)

\section{Water Fountains}

The presence of a water element will not only support the beauty of the site but also to reduce the impression of monotony. As a natural element, water can be a prominent manifestation in the landscape. Water can be used in ponds or as a fountain because it can reflect lights. The sound produced is also loud enough to invite curiosity to passersby.

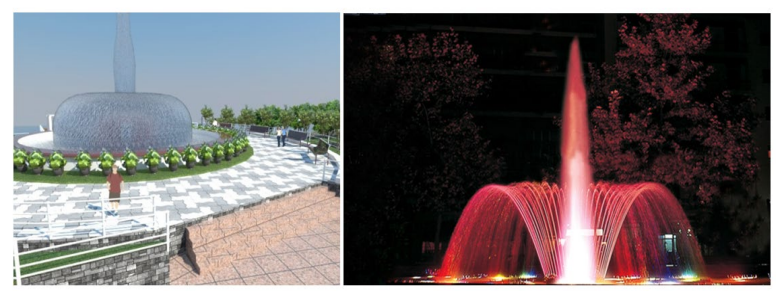

Figure 7. Focal Point

\section{3) Garden and Greening Design}

In order to get an outdoor space that is functional, attractive and comfortable, of course the concept of landscaping and greening is to be considered. The concepts of landscaping and greening are grouped into different spaces and activities, namely:

a. Arrangement on open space (open space scape)

b. Optimizing open spaces of land with functions that are recreational and a place of social interaction. Like a plaza, and open gardens.

c. Use of parks as a means of recreation, sports and social interaction.

d. Planting types of trees with thick and beautiful leaves that function as land boundaries.

e. Planting grass and shrubs on open land, functions as a solar thermal absorber, as well 
f. Planting shade trees as roadblocks and directing circulation.

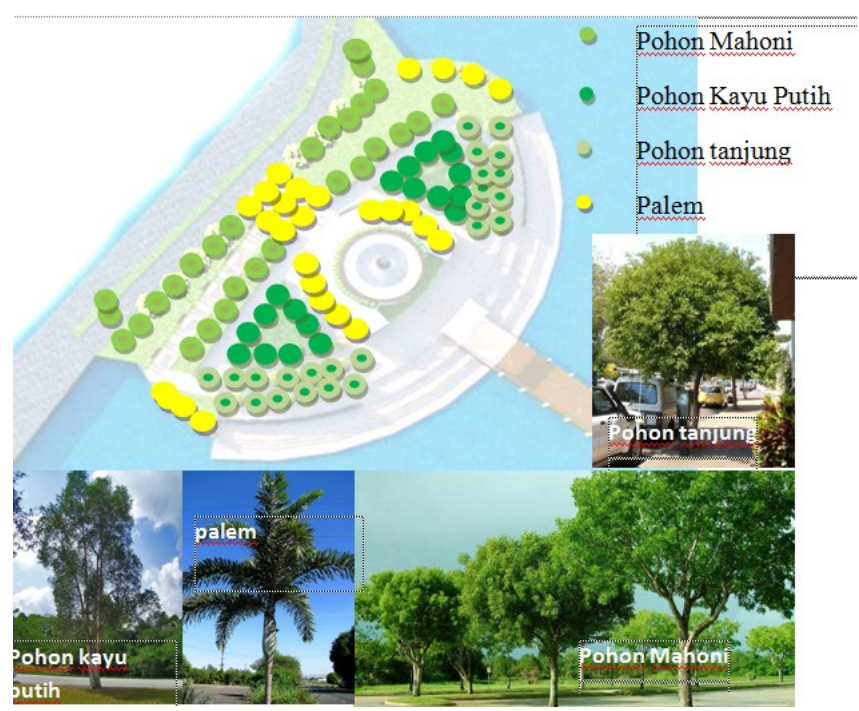

Figure 8. Garden and Greening Design

Green plants usually have a dual function, that is, as a source of energy production for all types of organisms and the other function is the function of an active water pump that sucks water through the roots onto the leaves and maintains the transpiration process [7].

\section{4) Floor material type}

The use of floors in the design of public open spaces in the seaside area of Ternate, not only prioritizes the aesthetics of the area, but also prioritizes environmental balance, and the use of flooring materials consisting of mini elephant grass, wood and paving stones. Details for floor material can be seen in the following picture;

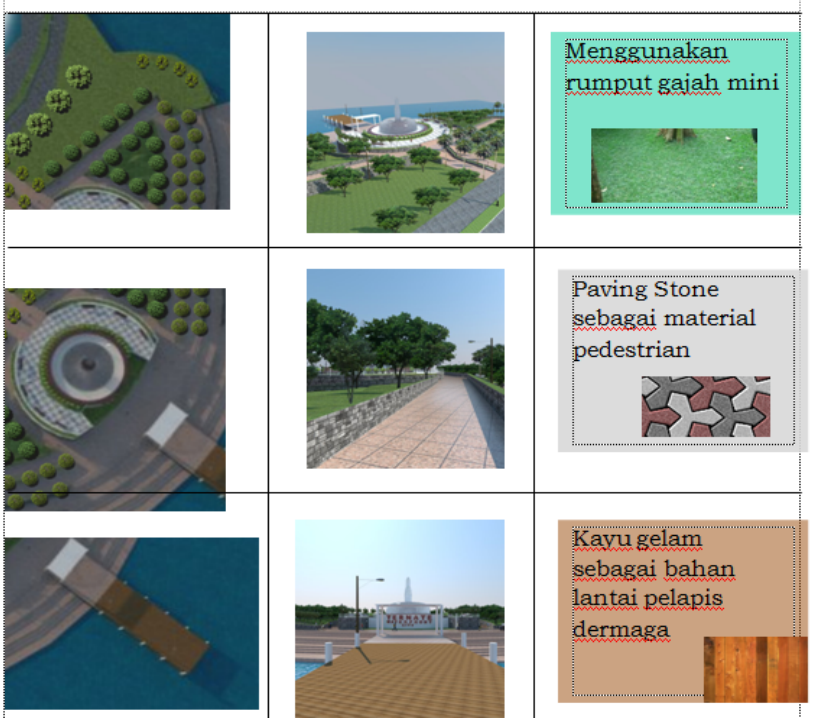

Figure 9. Floor pavement material elements
5) Lighting System Design

a. Type of Lighting Source (lamp usage). LightEmitting Diode or LED is a semiconductor device measuring just a few millimeters.

b. Lighting. The lighting concept, which was designed in the public spaces of the Ternate seaside area, not only functions as a lighting area, but also prioritizes the design aesthetics of public spaces. For more details related to lighting plans in open space in the seaside area of Ternate City, can be seen in the following figure;
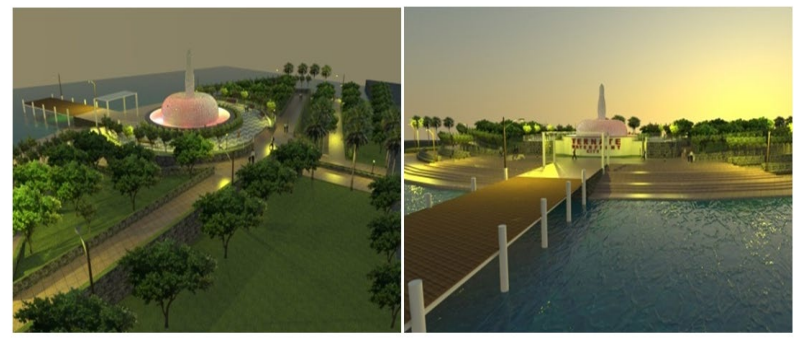

Figure 10. The Concept of Lighting Arrangements

This exterior lighting system is designed using photovoltaic panels commonly referred to as solar panels along with batteries. the lighting system has been designed so that sunlight hits the solar panel and charges the battery during the daytime period. The battery can then supply power to the lighting system during the night period [8].

\section{6) Use of Solar Cell Systems}

Related to the use of solar cell power in public open space areas, its use is focused on moving water pumping machines, turning on lights at night and watering plants automatically in public space areas, where all of these activities require room control which in addition functions as a room controller, also serves as a pumping station for engines, travo, batteries and panels.

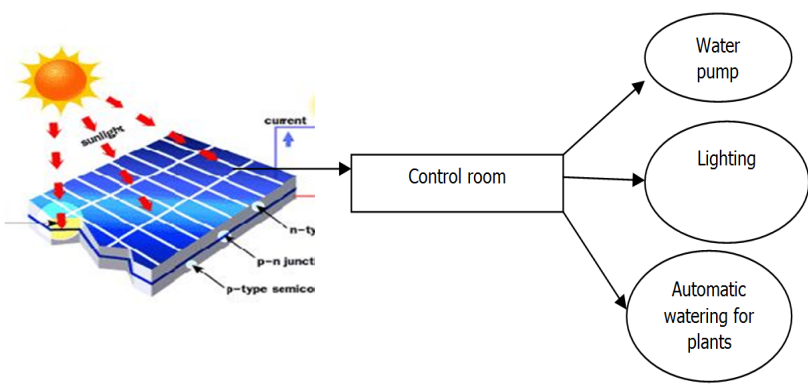

Figure 11. Electricity Distribution Scheme (Solar Cell)

Consideration that the control room in an open space does not interfere with community activities, the installation of the electrical network used must be safe and outside the reach of the community, so that the ideal installation is with an underground system. 


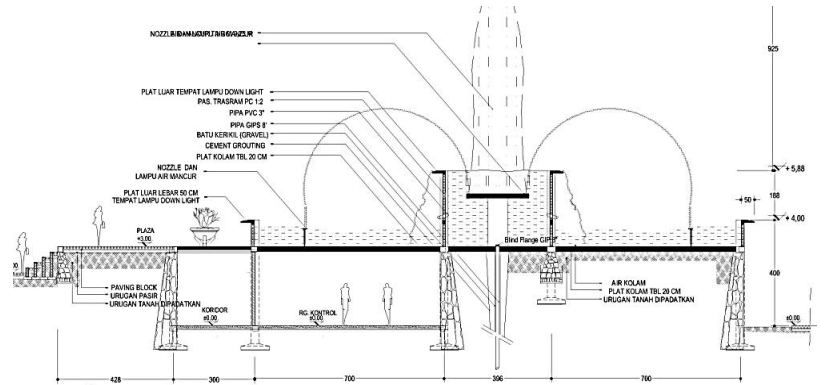

Figure 12. Details of the Control Room and Fountain Section

\section{7) Design of Activity Functions}

The design of the function of public open space activities in the waterfront area of Ternate City, is oriented towards physical and functional activities.

a. Based on Physical Properties. Based on physical properties, outdoor space is categorized as; Active space / passive space. where these spaces are formed functions as a space for sports activities, walking, and playing. The shape of the outer space is in the form of plazas and fields, while for the passive / negative space is the space that was formed not for the place of activity as a human place, and the form of the outer space is in the form of passive parks and focal points. One example of a passive outer space is a fountain where the fountain can only be seen as a Focal Point's beauty.

b. Based on Activity Functions. Based on the function of its activities, outer space is categorized Functional, meaning that the outer space is formed by the existence of certain functions / uses such as:

1. Active spaces: play, sports, recreation, concerts, performing arts

2. A place to switch activities or wait

3. Economic function: a place for street vendors

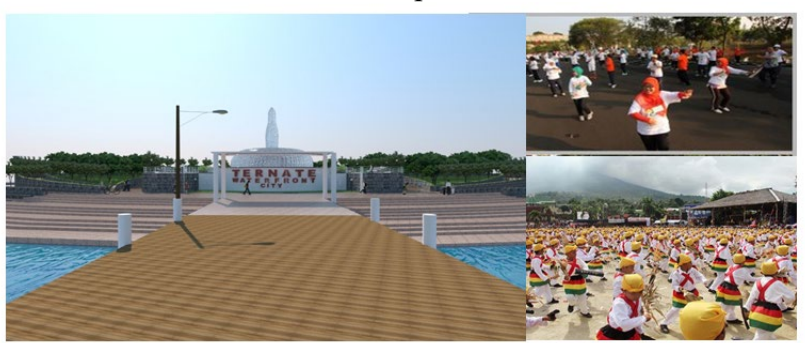

Figure 13. Dock as Active Space

One of the elements of the outer space (pier) in the design of public open space in the waterfront area that can function as an active space (where jogging, gymnastics, sunbathing and places to hold art performances).

While the function of the Ecological category is plants, meaning that the outer space is formed by considering its ecological function;

a) Source of air refreshment (absorbs $\mathrm{CO} 2$ and produces $\mathrm{O} 2$ ),

1. As an absorber and controller of rainwater, too

2. As a controller of certain ecosystems

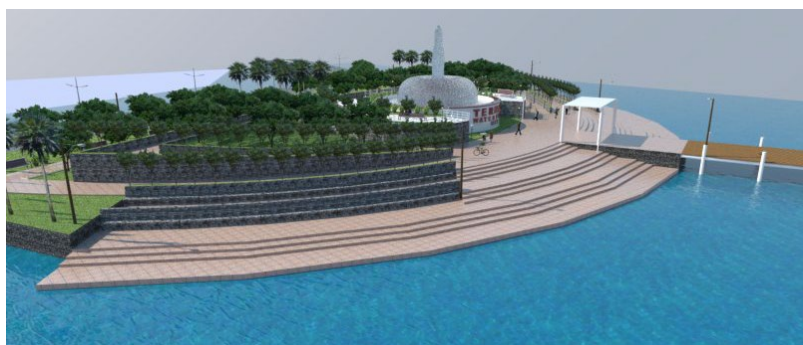

Figure 14. Landscape as an Ecological Function

\section{8) Form Transformation Design}

Human behavior occurs in space, and spatial planning provides a diverse environment and is an opportunity for people to interact [9]. The interaction of people with the environment is manifested in the understanding of regional symbols. Regional symbols in Public Open Spaces are identified with the characteristics or habits of the local community. Or it can be in the form of symbols that have been transformed into new forms.

For the transformation of the shape used in the design of the Public Open Space in the seaside area of Ternate using the form of stingrays, where stingrays are a symbol of Ternate City, in addition to being a symbol, stingrays have a dynamic shape with a wide open body.

For further details related to the transformation of forms in public open design in the seaside area of Ternate City, can be seen in the following figure;

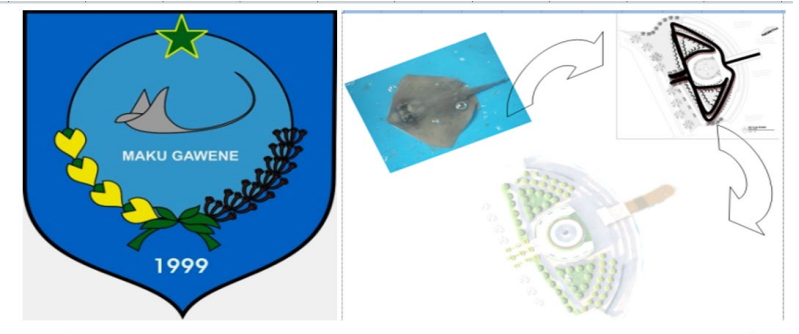

Figure 15. Transformation of Public Open Space Design Forms

All designs, both public open spaces and building designs must follow the rules, requirements, and government regulations that have been made. All parties, both government and developers must comply with the standard rules and regulations that have been prepared both from a technical and administrative point of view. Deviations that occur will cause difficulties and uneven development implementation [10]. Especially meeting the needs of public open space in urban areas.

\section{CONCLUSION}

Public open space design with the concept of Sustainable Architecture in the city of Ternate can be an alternative to meet the needs of open space that is still lacking. by choosing the location of the design of a public open space on the land of the Hypermart building, can be a solution to create the concept of the city of waterfornt in the area of Tapak $I$ in the city of Ternate 


\section{ACKNOWLEDGMENT}

The Thank you to Fakultas Teknik for giving researchers the opportunity to participate in the 5th FANRES International conference 2019. Thank you also to the 5th FANRES International conference 2019 committee for holding a seminar at Universitas Khairun.

\section{REFERENCES}

[1] L. Tangkuman, Dwi JuwitaTondobala, "Arsitektur Tepi Air," Media Matrasain, vol. 8, no. 2, pp. 4054, 2011.

[2] Hanni Adriani, "proses perancangan pertamanan di pt . envirospace consultants indonesia," 2011.

[3] Bethany Steiner, "Trail Bridge Recreation Area Master Plan December 2012," no. December, 2012.

[4] P. Fazeli, A. Shakarami, A. Mohammad, and M. Mehre, "Evaluation of Determinant Qualities Affecting Urban Landscape Aesthetics in Sustainable Urban Design ( A Focus on Serial Vision Heterogeneity ) Case Study: Jolfa Alley in Isfahan," vol. 2, no. 5, 2014.

[5] D. Helbing and I. I. Institut, "Models for Pedestrian Behavior Individual behavior," pp. 1-13.

[6] S. Riyadi, "Media ruang luar dalam sistem visual ruang publik (studi kasus: kawasan simpanglima semarang)." 2002.

[7] W. Ripl, "Water: the bloodstream of the biosphere," no. November, pp. 1921-1934, 2003.

[8] P. E. S. Lazarus and A. E. Hagarman, "Patent Number : 5,149,188," 1992.

[9] A. S. A. Mishra and R. K. Pandit, "Urban Transformation and Role of Architecture towards Social Sustainability," vol. 5, no. 7, pp. 16-20, 2013.

[10]E. Harisun, "Kajian Sistem Sertifikasi Laik Fungsi Bangunan Gedung," Media Eng., vol. 3, no. 1, pp. 14-22, 2013. 